Article

\title{
Beach and Dune Erosion: Causes and Interventions, Case Study: Kaulon Archaeological Site
}

\author{
Giuseppe Barbaro $^{1}\left(\mathbb{D}\right.$, Giandomenico Foti $^{1, *(\mathbb{D}}$, Giuseppina Chiara Barillà ${ }^{1}\left(\mathbb{D}\right.$ ) and Ferdinando Frega ${ }^{2}(\mathbb{D})$ \\ 1 DICEAM Department, Mediterranea University of Reggio Calabria, Via Graziella loc. Feo di Vito, \\ 89122 Reggio Calabria, Italy; giuseppe.barbaro@unirc.it (G.B.); chiara.barilla@unirc.it (G.C.B.) \\ 2 Department of Civil Engineering, Calabria University, 87036 Arcavacata di Rende, Italy; \\ ferdinando.frega@unical.it \\ * Correspondence: giandomenico.foti@unirc.it
}

Citation: Barbaro, G.; Foti, G.; Barillà, G.C.; Frega, F. Beach and Dune Erosion: Causes and Interventions, Case Study: Kaulon Archaeological Site. J. Mar. Sci. Eng. 2022, 10, 14. https://doi.org/10.3390/ jmse10010014

Academic Editor: Rodger Tomlinson

Received: 9 October 2021

Accepted: 22 December 2021

Published: 24 December 2021

Publisher's Note: MDPI stays neutral with regard to jurisdictional claims in published maps and institutional affiliations.

Copyright: (C) 2021 by the authors. Licensee MDPI, Basel, Switzerland. This article is an open access article distributed under the terms and conditions of the Creative Commons Attribution (CC BY) license (https:// creativecommons.org/licenses/by/ $4.0 /)$.

\begin{abstract}
The dune systems are very important from an environmental, landscape, and coastal defense point of view within coastal areas. Currently, dune systems are significantly reduced compared to a few decades ago and, in Europe alone, dune systems have decreased by $70 \%$. During the same period, intense beach erosion processes have often been observed, and, currently, 30\% of the world's coasts are eroding. These processes have various causes, both natural and anthropogenic, and the knowledge of the causes of the erosive processes are very important for an effective planning and management of coastal areas and to correctly plan any interventions on dunes and beaches. The paper, through a case study, analyzes the beach and dune erosive processes, their causes, and the possible interventions. The case study concerns the archaeological site of Kaulon, located on a dune in the Ionian coast of Calabria (Italy). The beach near the site was affected by erosive processes and during the winter of 2013-2014, the site was damaged by two sea storms. To identify the causes of these processes, three erosive factors were analyzed. These factors are anthropogenic pressure, wave climate and sea storms, and river transport. The effects produced by these factors were assessed in terms of shoreline changes and of damage to the beach-dune system, also evaluating the effectiveness of the defense interventions. The main causes of the erosive processes were identified through the cross analysis of erosive factors and their effects. This analysis highlighted that in the second half of the last century the erosive processes are mainly correlated to anthropogenic pressure while, recently, natural factors prevail, especially sea storms. Regarding the interventions, the effects produced by two interventions carried out during the winter of 2013-2014, one built in urgency between the first and second sea storm and the other built a few years after the second sea storm were analyzed. This analysis highlighted that the latter intervention was more effective in defending the site.
\end{abstract}

Keywords: dune; erosion; wave climate; sea storms; longshore transport; river transport

\section{Introduction}

Coastal dunes are a habitat of important environmental and landscape value. Additionally, dunes are a natural costal defense because they act both as a reserve of sand and as a physical barrier to protect the territories behind [1-4]. This issue is particularly topical and important because of the significant anthropization processes that occurred from the second half of the last century. Indeed, these processes have totally or partially destroyed numerous dune systems, have altered the coastal equilibrium conditions, and have triggered beach and dune erosion. Currently, 30\% of the world's coasts are eroding [5-7] and, in Europe alone, dune systems have decreased by $70 \%$ [8].

Dunes are dynamic systems that vary spatially and temporally under the action of both natural and anthropogenic factors [9-12].

From the temporal point of view, there are long-term and short-term variations. Longterm variations are correlated to alterations in coastal, wind, and river sedimentary balance [13-16]. Often these alterations are caused by anthropogenic factors such as the 
construction of buildings, infrastructures, ports and coastal defense works in coastal areas [17], and the construction of hydraulic structures interfere with fluvial dynamics such as levees, dams, and inert drains from riverbeds $[18,19]$. On the other hand, the short-term variations are mainly related to natural factors such as single sea storm [20], cluster of sea storms [21,22], extreme flood events [23], or concurrent events [24-26] which cause coastal flooding [27]. Instead, a full dune recovery generally can take several decades [28].

From the spatial point of view, the erosive processes of the beach-dune system can vary greatly along the coast for various reasons, the main ones being linked to the geomorphological characteristics of the area and to the variability of the wave climate and of the longshore transport $[29,30]$.

The issue of morphological changes of coastal dunes and of the beach-dune system and the analysis of the related causes is widely analyzed in the scientific literature by analyzing real cases [31,32], with laboratory experiments [33-37] and applying analytical and numerical models [38-40]. Indeed, these variations can be analyzed both in probabilistic terms [41,42] to identify critical thresholds of sea storms that cause dune erosion [43] and in terms of the beach response to the action of the most intense sea storms [44]. From this point of view, monitoring the dune-beach system at different time scales is of particular importance, also using remote sensing [45-49].

The analysis of the causes of erosive phenomena is of fundamental importance to quantify and predict the vulnerability of beach-dune systems on different timescales and to correctly plan any interventions on dunes and beaches [50-60].

Often, the analysis of these causes focuses on extreme events [61] or on clusters of extreme events [62] or on single factors such as coastal erosion. Instead, a complete analysis is one that considers the largest possible number of the main natural and anthropogenic factors that influence the dune systems. Examples of these analyses are by Pye and Neal [31], who analyzed both the effects of sea storms and the effects caused by the construction of a wall and by a dredge spoil dumping. Subsequently, Cohn et al. [63] analyzed morphological and environmental parameters, such as beach slope and total water level (TWL), by numerical modeling with XBeach. Dissanayake et al. [64] have developed a two-step framework that classifies sea storms and analyzes their impacts on beach-dune systems. Hird et al. [65] analyzed both hydrodynamic forcing and river channel evolution over a 10-year time interval. Finally, Sanromualdo-Collado et al. [66] analyzed the impacts caused by the construction of beach equipment, services, and uses on beach-dune systems. The paper, through a case study, analyzes the beach and dune erosive processes, their causes, and the possible interventions. The paper does not analyze a single erosive factor, but it is a complete analysis, which considers the effects of anthropogenic pressure, wave climate and sea storms, and river dynamics. Furthermore, the paper analyzes the effects produced on the dune-beach system by a temporary intervention, carried out urgently due to the damage caused by the storms of winter 2013-14, and by a subsequent intervention. The case study concerns the archaeological site of Kaulon, located on the dune system in the Ionian coast of Calabria (Italy). Kaulon's erosive phenomena have already been analyzed by Barbaro et al. $[67,68]$ but it was an incomplete analysis due to the limited data available. This paper, on the other hand, uses recent and current data and expands the time interval of analysis to better understand the causes of erosive phenomena.

\section{Materials and Methods}

This section is divided into two parts. The first part describes the geographical, geomorphological, sedimentological, and hydrological characteristics of the study area. The second part describes the methodology used to analyze beach and dune erosion processes and their possible causes.

\subsection{Site Description}

The site is located on the Ionian coast of Calabria (Southern Italy), near the town of Monasterace Marina and between the mouth of the rivers Assi and Stilaro (Figure 1). The 
coastline has an inclination of $15^{\circ}$ from the North. The site is affected by the prevalent winds that blow from the South and South-Easterly and from the North and North-Easterly directions. The most severe sea storms mainly come from the South and South-Easterly direction, where the fetch is up to $700 \mathrm{~km}$, and they are prevalent in the winter season. The archaeological site extends along the coast for $1 \mathrm{~km}$ and consists of an ancient town, a Doric Temple, and a Pillbox (Figure 1) which are inside a sand dune along the coast located at an altitude of about $8 \mathrm{~m}$.

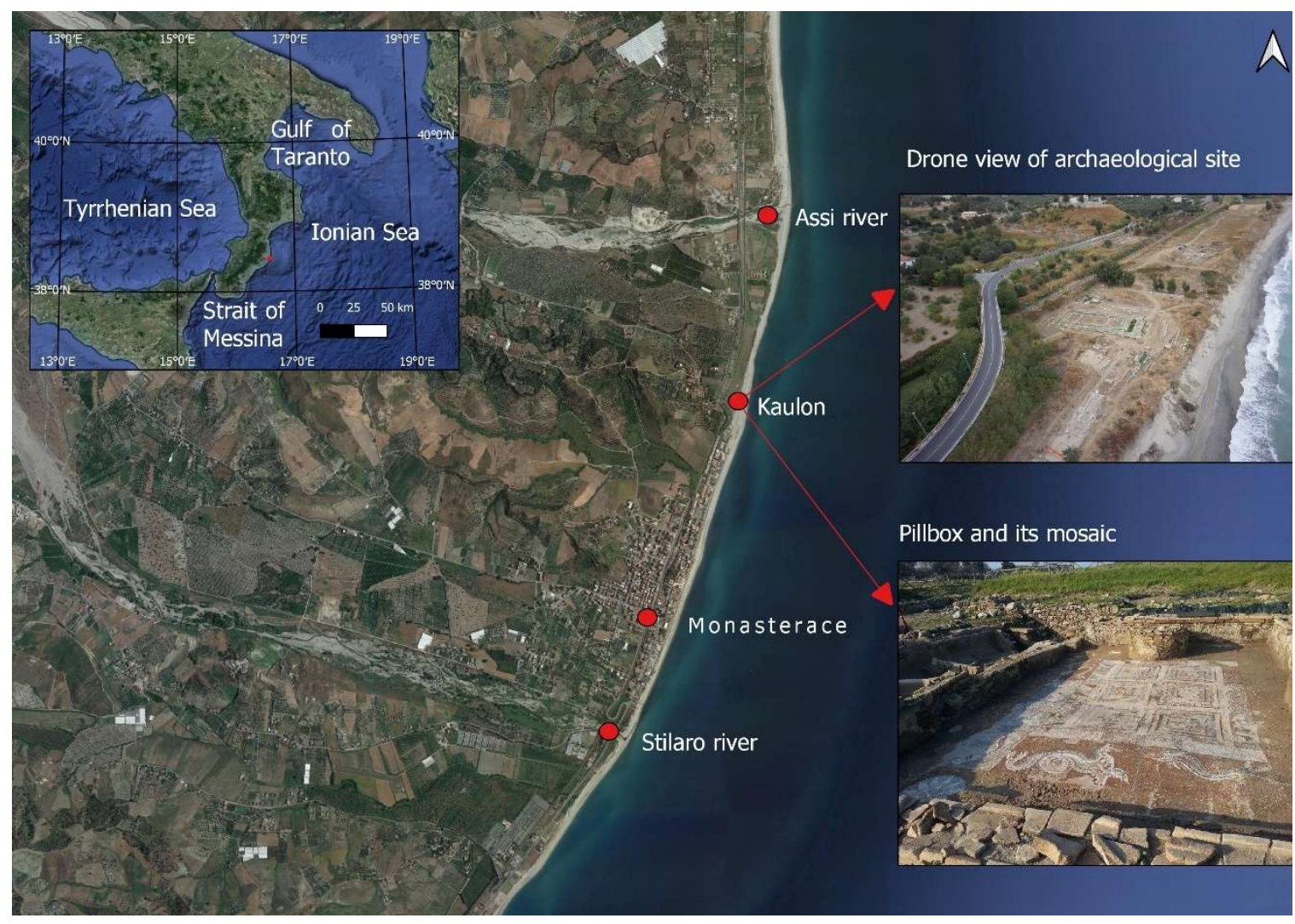

Figure 1. Location of the study area.

The study area is characterized by recent tectonic uplift accompanied by compressive phenomena eastward and distensive and sinking phenomena to the west. The intense and recent tectonic activity has provided a morphology subject to intense erosion and gravitational processes as occurs in many rocks outcropping in other zones of Calabria [69]. The geological formations of the area are sedimentary rocks of Holocene-Recent age overlapped to the oldest sedimentary rocks (Mio-Pliocene-Pleistocene) and to crystalline-metamorphic units of Paleozoic age. Overall, the litho-stratigraphic sequence, starting from the most ancient rocks, can be summarized as follows: clays and polychrome silts (Miocene Inf.Med.), clays and whitish marl (Lower-Middle Pliocene), conglomerates and sands (Pliocene Sup.-Calabriano), sandstones and clay silts (Middle-Superior Pliocene), conglomerates and mica sands (Sup. Pliocene-Calabriano "Ghiaie di Messina"), conglomerates and sands (Pleistocene), debris fan (Holocene), solifluction products (Holocene), stabilized alluvial deposits (Holocene); coastline and mobile alluvial deposits (Holocene), stabilized sand dunes, mobile sand dunes.

From the geomorphological point of view, the area is characterized by a narrow coastal plain and by hills that connect to the reliefs of the Serre. The coast is characterized by a low beach, a well-developed dune system and a sea bottom with moderate slope (2-3\%). From the sedimentological and grain size distribution point of view, the beach sediments are composed of sand and light grey gravels, with $\mathrm{D}_{50}$ equal to $5 \mathrm{~mm}$ next to the isobaths of $+1.0 \mathrm{~m}, \mathrm{D}_{50}=0.7 \mathrm{~mm}$ next to the isobaths $-3.0 \mathrm{~m}$, and $\mathrm{D}_{50}$ equal to $0.82 \mathrm{~mm}$ at the isobaths 
$-7.0 \mathrm{~m}$ [70]. From the hydrological point of view, the hydrography is characterized by a series of rivers (called fiumare and typical of Calabria) with dendritic and fin patterns, with high drainage density, perpendicular to the coastline with a typical braided course. Generally, most of the Calabrian rivers are characterized by high slopes, modest time of concentration and torrential regime so floods occur suddenly [71,72]. For these reasons, river sediment transport is mainly related to Soil Erosion by Water (WSE) [73]. The study area and, in general, most of the Calabrian rivers are particularly prone to WSE [74] which also influence shoreline evolution [75,76].

\subsection{Methodology}

The methodology proposed in this paper aims to evaluate the causes of the erosive processes observed near the archaeological site of Kaulon. To identify these causes, erosive factors and their effects on the study area were examined, according to the flow chart of Figure 2. In detail, three main erosive factors on the beach-dune system were analyzed. These factors are anthropogenic pressure, wave climate and sea storms, and river transport. The effects were assessed in terms of shoreline changes and of damage to the beachdune system.

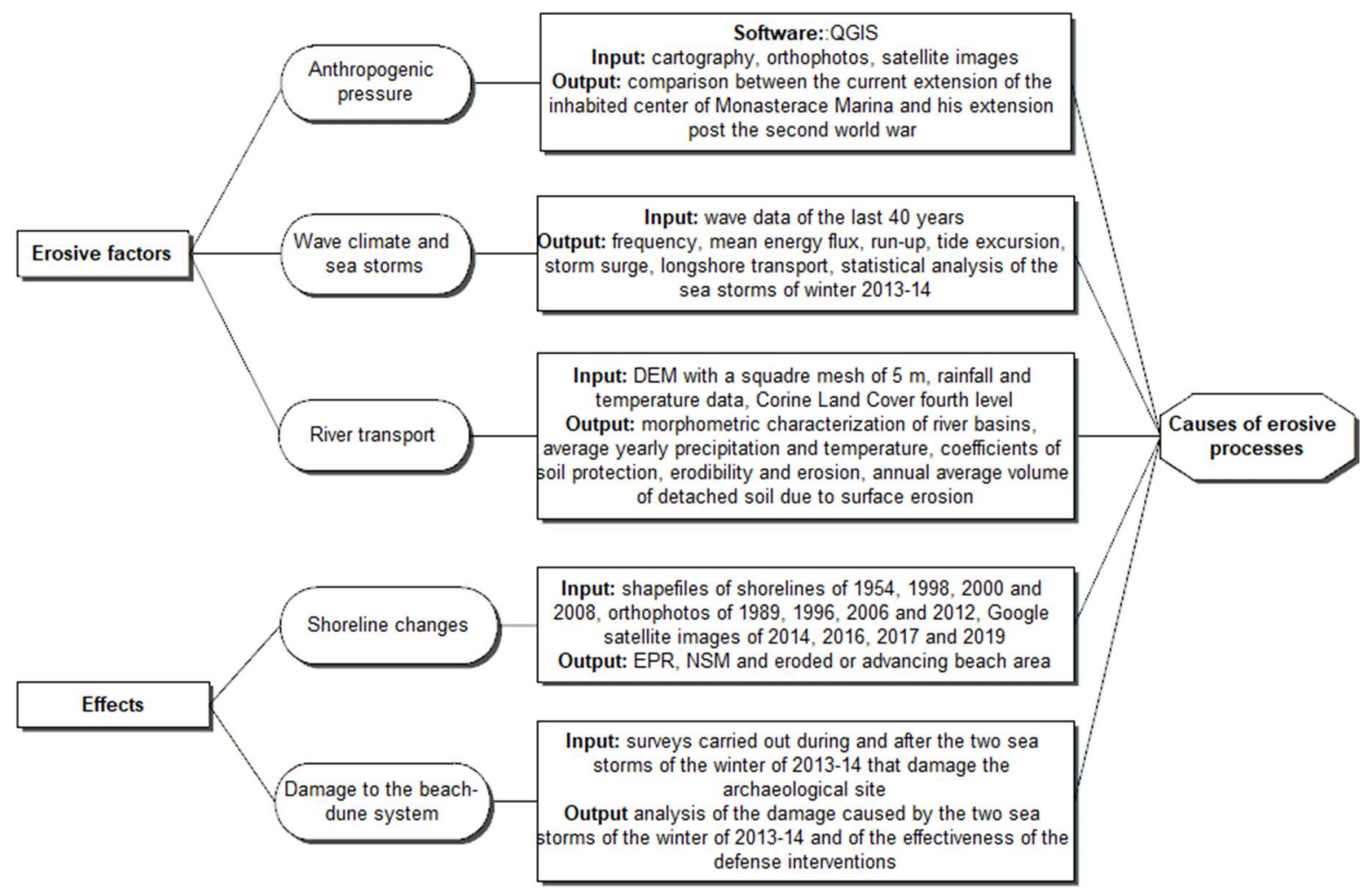

Figure 2. Flow chart of the proposed methodology.

\subsubsection{Anthropogenic Pressure}

The analysis of the anthropogenic pressure was carried out on QGIS through the overlap and the comparison of various cartography data, which consists of CASMEZ, "Cassa del Mezzogiorno", cartography of 1954, available in the Open Data section of the Calabrian Geoportal (http:/ / geoportale.regione.calabria.it/opendata, accessed on 1 December 2021); orthophotos of 1989 and 1996 available as a WMS service in the Open Data section of the Italian Geoportal (http:/ / www.pcn.minambiente.it/mattm/servizio-wms/, accessed on 1 December 2021), and the most recent Google satellite image of 2019. The main aim of this analysis concerns the comparison between the current extension of the inhabited center of Monasterace Marina and his extension post the second world war, before the considerable anthropic pressures observed in most of the Calabrian and Italian territories. Furthermore, 
by comparing the current extension with that of the 1990s, it was possible to better date the anthropization process.

\subsubsection{Wave Climate and Sea Storms}

This phase concerns the evaluation of the wave climate and the statistical analysis of the sea storms of winter 2013-2014, which damaged the dune and the archaeological site. Regarding wave climate, the following was calculated: frequency of occurrence of sea state (hereinafter referred to as frequency), mean energy flux, run-up, tide excursion, storm surge, and longshore transport. Frequency and mean energy flux identify the directions of frequent and intense sea storms, respectively. Furthermore, the comparison between the estimated run-up, tide excursion and baric and storm surge values, and the altimetry of the study area was used to evaluate whether these parameters can directly affect the archaeological site. Regarding longshore transport, the estimated value was compared with the river contribution to understand whether the two forcing are on average equivalent or not. Finally, the analysis of the wave climate is the basis for the statistical analysis of the sea storms of winter 2013-2014.

The input data are the wave data from the last 40 years, available in the database developed by the MeteOcean group of the University of Genoa (http: / / www3.dicca.unige. it/meteocean/hindcast.html, accessed on 15 September 2021). This data was reconstructed from the Climate Forecast System Reanalysis (CFSR) database.

The time series is relative to point 7624, with coordinates $16.638 \mathrm{E}$ and $38.46 \mathrm{~N}$ and located at a depth of over $110 \mathrm{~m}$. The time series consists of 332,884 sea states, for each of which significant wave height, mean and peak periods, and wave direction are available. These data were grouped in sectors of $10^{\circ}$ each and the time series was analyzed both entirely and divided into intervals of 10 years each.

Starting from time series data, the frequency and the mean energy flux $\Phi$ were calculated. The frequency of the generic sector is the ratio between the number of sea states from that sector and the total number of registered sea states. The mean energy flux of the generic sector is the sum of the energy flux of each sea state from that sector, that depends on the specific gravity of the water, on the peak period, on the square of the significant height and on the frequency. Run-up was estimated by the Stockdon et al. model [77]. This model is based on the following equations and depends on the foreshore beach slope $\beta_{\mathrm{f}}$, on the significant wave height at deep water $\mathrm{H}_{0}$, on the wavelength at deep water $\mathrm{L}_{0}$, and on the Iribarren number $\xi_{0}$.

$$
\begin{gathered}
\mathrm{R}_{\mathrm{u} 2 \%}=1.1\left\{0.35 \beta_{\mathrm{f}}\left(\mathrm{H}_{0} \mathrm{~L}_{0}\right)^{1 / 2}+\frac{1}{2}\left[\mathrm{H}_{0} \mathrm{~L}_{0}\left(0.563 \beta_{\mathrm{f}}^{2}+0.004\right]^{1 / 2}\right\} \text { for } \xi_{0}<0.3,\right. \\
\mathrm{R}_{\mathrm{u} 2 \%}=0.043\left(\mathrm{H}_{0} \mathrm{~L}_{0}\right)^{1 / 2} \text { for } \xi_{0} \geq 0.3,
\end{gathered}
$$

The slope was estimated by analyzing the open access bathymetry available on the EMODNET portal (https: / / www.emodnet-bathymetry.eu/, accessed on 1 December 2021) while significant wave height and wavelength at deep water were calculated starting from the time series for different return times $(1,10,20,50,100,200$, and 500 years). To estimate the tide excursions, the recordings of the tide gauges of Crotone and Reggio Calabria were analyzed, also the Tide Tables of the Italian Marine Hydrographic Institute [78] and scientific papers were consulted, especially that of Sannino et al. [79]. The storm surge was estimated using the Bretschneider model [80]. This model is based on the following equation and depends on the depth at the shelf edge $d_{1}$, on the depth near the coast $d_{2}$, on the wind drag coefficient $K$, and on the length of the wind fetch $L$. To this value the surge caused by the minimum atmospheric pressure recorded during an atmospheric disturbance was added, considering that a barometric decrease of $1 \mathrm{mbar}$ compared to the normal value of 1013 mbar causes a surge of $1 \mathrm{~cm}$.

$$
\mathrm{S} / \mathrm{d}_{1}=\left(\left(\mathrm{K} \mathrm{U}^{2} \mathrm{~L}\right) /\left(\mathrm{g} \mathrm{d}_{1}^{2}\left(1-\mathrm{d}_{1} / \mathrm{d}_{2}\right)\right) \ln \left(\mathrm{d}_{1} / \mathrm{d}_{2}\right)\right.
$$


Longshore sediment transport has been evaluated by the Tomasicchio et al. model [81]. This model is of general validity, it is based on a mobility index depending on the granulometry of the beach sediments and was obtained starting from the model of Lamberti and Tomasicchio [82]. The main input data of the Tomasicchio et al. model are significant wave height $\mathrm{H}_{\mathrm{s}}$, peak wave period $\mathrm{T}_{\mathrm{p}}$, off-shore wave angle $\theta_{0}$, and nominal diameter of the unit $\mathrm{D}_{\mathrm{n} 50}$. Using these data, characteristic wave height $\mathrm{H}_{\mathrm{k}}$, mean wave period $\mathrm{T}_{\mathrm{m}}$, wave length L, wave celerity $\mathrm{c}$, wave group celerity $\mathrm{c}_{\mathrm{g}}$, characteristic wave height at breaking $\mathrm{H}_{\mathrm{k}, \mathrm{b}}$, characteristic wave angle at breaking $\theta_{\mathrm{k}, \mathrm{b}}$, modified stability number $\mathrm{N}_{\mathrm{s}}{ }^{*}$, length of displacement $l_{d}$, number of displaced particles at the end of 1000 wave attack $N_{\text {od }}$, longshore transport measured as number of units per wave $S_{N}$ and, finally, longshore transport rate in volume per unit time $\mathrm{Q}_{\mathrm{LT}}$ were calculated, as shown by the flow chart of Figure 3. Therefore, the granulometry described in Section 2.1 and the wave time series were used as input data.

The statistical analysis of the sea storms of winter 2013-2014 consists of the evaluation of the maximum significant wave height, of the wave direction at the peak of significant wave height, and of the duration of each storm. From these data, the return periods of each sea storm were calculated.

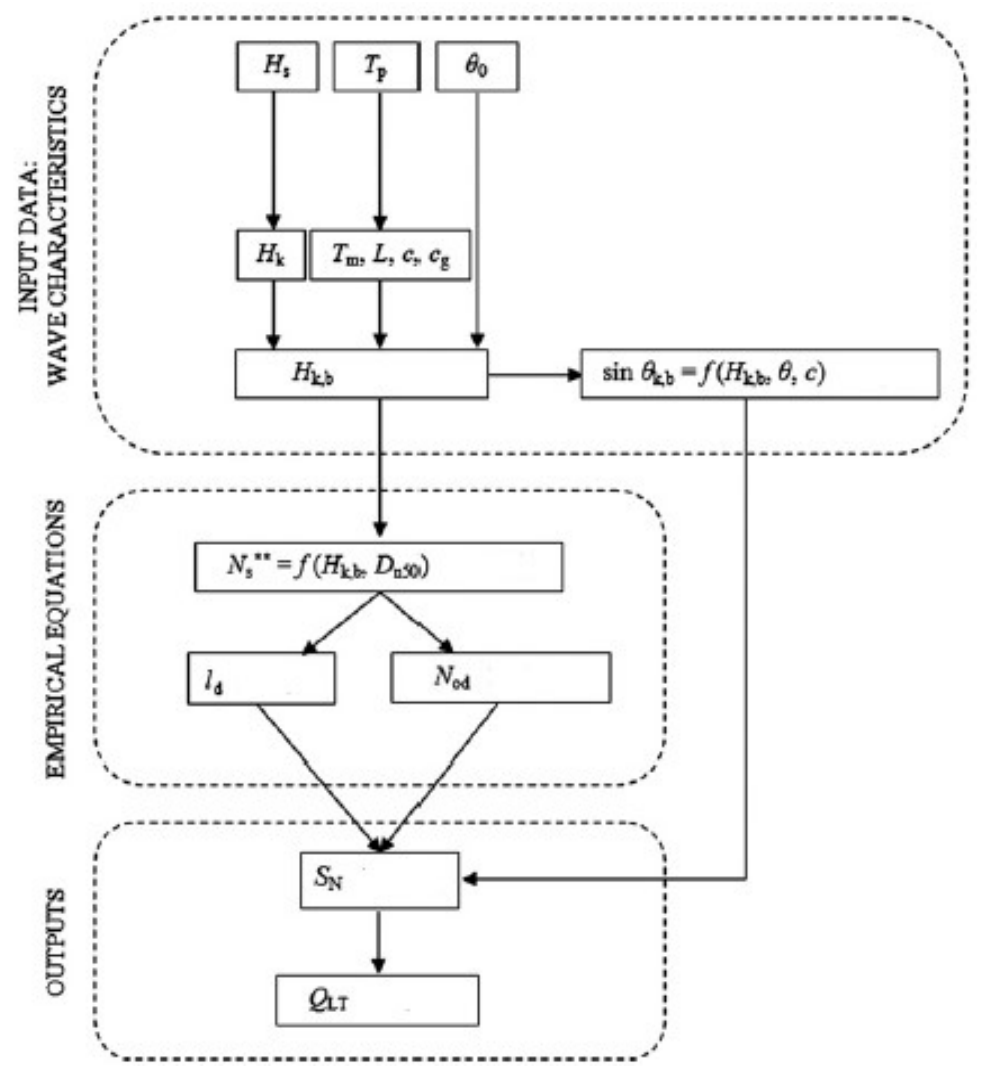

Figure 3. Flowchart of the Tomasicchio et al. model [81].

\subsubsection{River Transport}

The aim of this phase concerns the analysis of river transport in terms of average volume of detached soil due to surface erosion. This parameter was compared with the longshore transport rate to understand whether the two forcing are on average equivalent or not. River transport was estimated using the Gavrilovic model [83], which is particularly reliable in basins where sediment transport is mainly related to WSEs as in this case study. The Gavrilovic model is based on an analytical equation to determine the annual volume of detached soil due to surface erosion. This equation depends on the morphometric characteristics of the river basin, such as the area, the perimeter, the average slope, the average height, the main stream length, the total stream length, on the average yearly 
precipitation and temperature, and on some coefficients related to the soil protection (a function of the type of vegetation cover), to the erodibility (a function of type of rock), and to the type of basin erosion.

Preliminarily, it was necessary to identify and morphometrically characterize the basins at the edges of the study area, Assi and Stilaro river, using QGIS. In addition, for each basin land uses were analyzed to estimate the coefficients of soil protection, erodibility and erosion, and rainfall and temperature time series were analyzed to estimate the average yearly precipitation and temperature.

In detail, the identification of the river basins and their morphometric characterization was carried out by starting with the DEM with square mesh of $5 \mathrm{~m}$ available in the OpenData section of the Calabrian Geoportal (http:/ / geoportale.regione.calabria.it/, accessed on 15 September 2021). For each basin, the area, the perimeter, the main stream length, the total stream length, the maximum and the average heights, the average slope, the Horton order, the Gravelius index, and the time of concentration were calculated. The estimation of the last parameter was undertaken using the formulas of Giandotti [84], Kirpich [85], and NRCS [86].

The average yearly precipitation and temperature values of each basin were estimated from the time series of rainfall and temperature records available in the Historical Data section of the Calabrian Multi-Risk Functional Center (http:/ / www.cfd.calabria.it/, accessed on 15 September 2021). Preliminarily, the rainfall and temperature gauges were identified with statistically significant time series in the Assi and Stilaro River basin and in its neighboring areas. For each gauge, the registration period, the number of years available, the elevation, the weight, estimated on QGIS using the Thiessen polygon method [87,88], and the average yearly precipitation and temperature were analyzed. The average yearly precipitation and temperature values of each basin were calculated as a weighted average of the values recorded by each gauge.

The land cover data used was from the Corine Land Cover project fourth level relating to the year 2018 and freely available on the government agency website "Istituto Superiore per la Protezione e la Ricerca Ambientale (ISPRA)" (https:/ / www.isprambiente.gov.it/it/ attivita/suolo-e-territorio/copertura-del-suolo/corine-land-cover, accessed on 15 September 2021). A value of each of the coefficients of soil protection, erodibility, and erosion was associated with each category of land use of the Corine Land Cover. The average values of these coefficients of each basin were calculated as a weighted average of the coefficient values of each land use category, considering the area of each land use category as weight.

\subsubsection{Shoreline Changes}

The analysis of the shoreline changes was carried out through the comparison of various cartography data, which consists of shapefiles of the historical shorelines of 1954, 1998, 2000, and 2008 taken from the Open Data section of the Calabrian Geoportal (http: / / geoportale.regione.calabria.it/opendata, accessed on 1 December 2021); orthophotos of 1989, 1996, 2006, and 2012 taken from the Open Data section of the Italian Geoportal (http:/ / www.pcn.minambiente.it/mattm/servizio-wms/, accessed on 1 December 2021); and satellite imagery of 2014, 2016, 2017, and 2019 provided by Google Earth.

The analysis was divided into three phases as follows. The first phase concerned the manual digitization of each missing shoreline, using QGIS for orthophotos of 1989, 1996, 2006, and 2012, thus obtaining shapefiles, and using the spatial analysis tools of Google Earth Pro for satellite imagery of 2014, 2016, 2017, and 2019, thus obtaining $\mathrm{kml}$ files then saved on QGIS as shapefiles. Both the orthophotos and the satellite images relate to the summer months, between May and September, so all the traced shorelines are relative to the summer profile. The second phase concerned the evaluation of the beach width for each transept. Finally, the last phase concerned the determination of shoreline rates of change using End Point Rate (EPR) and Net Shoreline Movement (NSM) statistics and the estimate of the eroded or advancing beach area. 
Regarding the first phase, the digitalization of the missing shorelines was carried out on a scale of 1:1000 on QGIS and at an eye altitude of $200 \mathrm{~m}$, corresponding to a higher scale, on Google Earth Pro. Generally, the uncertainties in the digitization phase concern georeferencing, the orthorectification process, the resolution of the different imagery sets, the digitizing uncertainty, the uncertainty in the identification of the wet/dry line, and any error caused by a variation in some factors affecting the shoreline change such as the seasonal cycle of erosion and deposition, and the impact of storms $[89,90]$. In this case, the reference line chosen was the wet/dry line. Additionally, the cartography data is all related to the summer period and no storm conditions were observed in any of the data, so the effects of seasonal variation and individual storms on shoreline change are of limited importance. Therefore, the uncertainties in the shoreline position are less than one meter and the shoreline changes were approximated to the meter. This accuracy agrees with the aims of the paper, which concern the evaluation of the erosion and advancement trends, and not their precise quantification. To estimate the tide excursions, the recordings of the tide gauges of Crotone and Reggio Calabria were analyzed, and scientific papers were consulted, especially that of Sannino et al. [79]. Therefore, in the study area the tidal excursion is of the order of tens of centimeters so the effects on the variation of the shoreline position are negligible.

Regarding the second phase, to analyze the shoreline changes of the entire physiographic sub-unit between the mouths of the Stilaro and Assi rivers, 15 transepts were traced, with an average spacing of the order of $200 \mathrm{~m}$. Additionally, the related baselines were identified for each transect. These lines identify the upper limit of the beach and correspond to promenades, roads, and structures. Regarding the third phase, the NSM and EPR and the eroded or advancing beach area between any two successive shorelines were calculated.

\subsubsection{Dune System Damage}

The archaeological site was damaged by two sea storms, both of which occurred in the winter of 2013-2014. The damage analysis was based on some surveys carried out during and after the sea storms. The aim of this phase concerns the assessment of the damage caused by the two sea storms to the archaeological site and the assessment of the effectiveness of two defense interventions carried out, one between the first and the second sea storm and the other a few years after the second sea storm.

\section{Results}

This section is divided into five subsections: anthropogenic pressure, wave climate and sea storms, river transport, shoreline changes, and dune system damage, similar to what is described in the methodology section.

\subsection{Anthropogenic Pressure}

To evaluate and date the anthropogenic pressure in the study area, cartography, orthophotos, and satellite images of different time periods were compared (Figure 4). The older source, from 1954 (CASMEZ cartography), and the most recent source, from 2019 (Google satellite image), were initially compared. The inhabited center of Monasterace Marina is located south of the archaeological site and was almost entirely built in the second half of the last century. Indeed, in 1954 there was only a strip of buildings around the main road. This strip was about $500 \mathrm{~m}$ long, was over $100 \mathrm{~m}$ from the shoreline behind the beach and there was no waterfront. Instead, the current extension of the built-up part is about $1500 \mathrm{~m}$ long, and buildings and promenade have been built instead of a large portion of the beach which has a current width of a few tens of meters.

Then, the 1989 and 1996 orthophotos were compared with each other and with the most recent satellite image. This comparison shows that most of the anthropization process took place between 1954 and 1989. Indeed, in 1989 there are the promenade and numerous buildings, both built where in 1954 there was a beach. Furthermore, the extension of the 
inhabited center in 1996 is almost the same as the current one, while between 1989 and 1996 only some buildings were built in the southern part of the inhabited center. Therefore, since 1996 the anthropization process has almost stopped. Finally, throughout the time interval analyzed, the anthropization process did not affect the archaeological site.

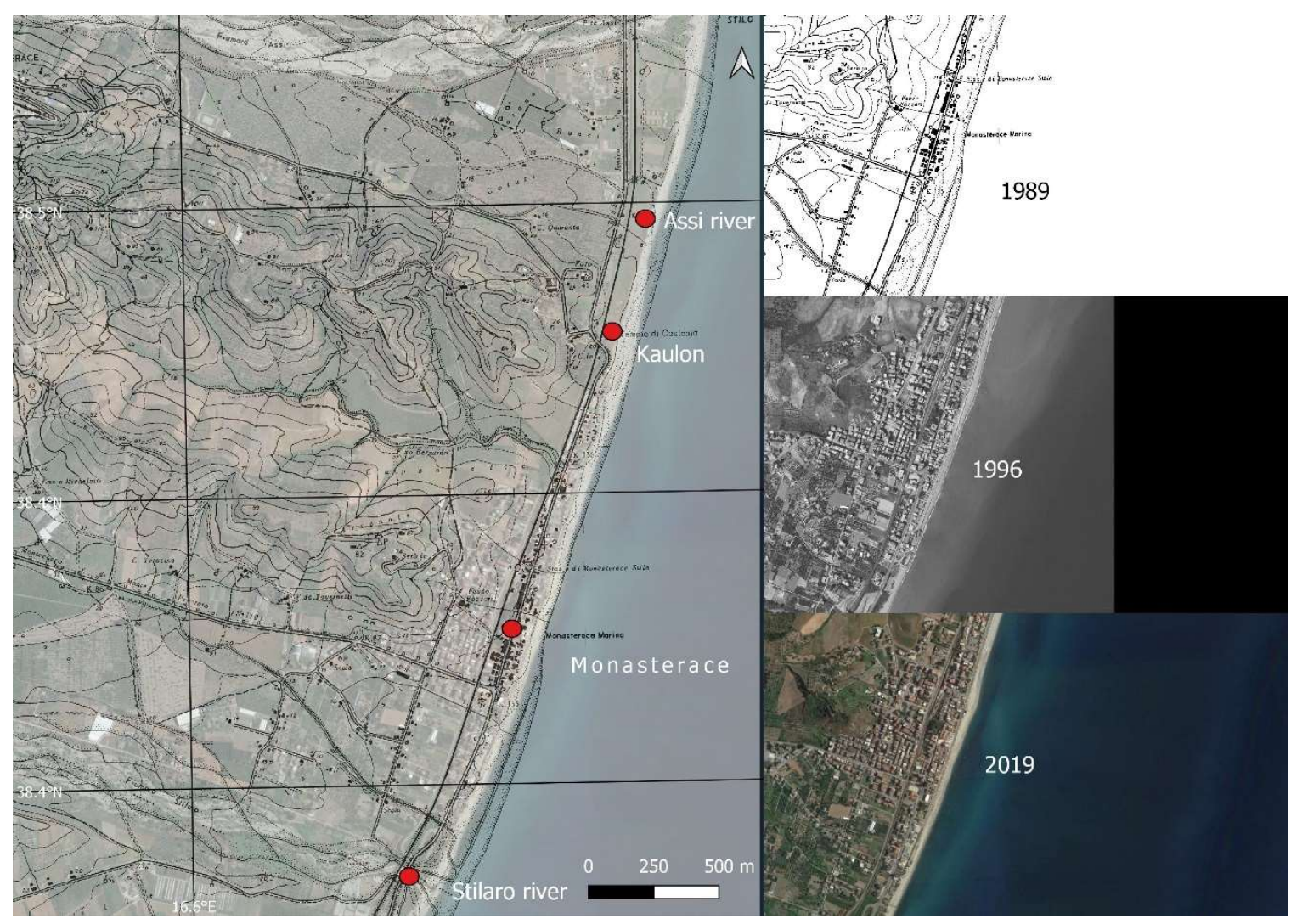

Figure 4. Large panel: overlap between CASMEZ cartography of 1954 and Google satellite image of 2019. Small panels: CASMEZ cartography of 1954 (up), orthophotos of 1996 (center), Google satellite image of 2019 (down).

\subsection{Wave Climate and Sea Storms}

The analysis of the wave climate of the last 40 years shows that the study area has been affected by frequent sea states from the northeast and south, with a maximum value of about $8 \%$ in the sectors centered on 180 and $190^{\circ}$ N. Furthermore, the mean energy flux graph has two peaks, one of about $450 \mathrm{~N} / \mathrm{s}$ in the sector centered on $50^{\circ} \mathrm{N}$, also with a relevant value in the adjacent sector centered on $40^{\circ} \mathrm{N}$, and with the main peak in the sector centered on $130^{\circ} \mathrm{N}$, with value higher than $650 \mathrm{~N} / \mathrm{s}$ and with relevant values in all sectors between $120^{\circ}$ and $160^{\circ} \mathrm{N}$. The sea states coming from sectors between 120 and $180^{\circ}$ are generated by the Scirocco winds, acting on fetches with lengths of several hundreds of $\mathrm{km}$. Instead, the sea states coming from the sectors around $50^{\circ}$ are generated by the winds of Grecale, acting on fetches with lengths of a few hundred $\mathrm{km}$. Therefore, the study area is subject to sea storms both significantly inclined and almost orthogonal with respect to the coast. The wave climate was also analyzed in shorter time intervals, of 10 years each, and the main results are summarized in Table 1. In detail, in each time interval the maximum values of significant wave height $\mathrm{H}_{\mathrm{s} \text {,max }}$, the mean energy flux and the main sector were evaluated. The analysis highlighted that the higher values of $\mathrm{H}_{\mathrm{s}, \max }$, almost $6.7 \mathrm{~m}$, were recorded in the decade of the 1980s, while in the following decades there are decreasing values, up to $5.9 \mathrm{~m}$ in the last decade. Instead, the mean energy flux initially grows between the 1980s and the 1990s and then decreases in the following decades. Instead, the main sector is always the one centered on $130^{\circ}$. 
Regarding the run-up values, slight variations are observed as the return period varies. Indeed, the values obtained are between $1 \mathrm{~m}$, with a return period of 1 year, and $2 \mathrm{~m}$, with a return period of 500 years. These slight variations depend mainly on the modest foreshore beach slope value, about 3\%. The tide excursion and the storm surge were added to this value. The maximum value of the tide excursion recorded by the tide gauges of Crotone and Reggio Calabria and by the Tide Tables of the Italian Marine Hydrographic Institute [78] is just over $20 \mathrm{~cm}$, according to the studies by Sannino et al. [79]. The storm surge calculated with the Bretschneider model [80] is just under $10 \mathrm{~cm}$. To this value the surge caused by the minimum atmospheric pressure recorded during an atmospheric disturbance was added, which in the Mediterranean assumes values no lower than 970 mbar. Therefore, the total storm surge value is of the order of $50 \mathrm{~cm}$. By adding the values of run-up, tide excursion, and storm surge, a value of less than $3 \mathrm{~m}$ is obtained. Due to the morphology of the territory, the archaeological site was not directly affected by these parameters as it is located at an altitude of about $8 \mathrm{~m}$ while the total value of run-up, tide excursion, and storm surge does not exceed $3 \mathrm{~m}$. Indeed, a barometric decrease of 1 mbar compared to the normal value of 1013 mbar causes a baric surge of $1 \mathrm{~cm}$.

Additionally, the longshore transport evaluated by the Tomasicchio et al. model [81] is about 90,000 $\mathrm{m}^{3}$ /year and is on average directed by South from North direction. However, the study area is subject to sea storms coming from both South-East and North-East directions so there can be a significant longshore transport also from North to South direction.

The statistical analysis of the sea storms that occurred in the winter of 2013-2014 (Table 2), which damaged the dune and the archaeological site, highlighted that these are statistically frequent sea storms. Indeed, the one that occurred between November and December 2013 reached a maximum significant wave height of $5.21 \mathrm{~m}$, lasted $74 \mathrm{~h}$, the direction at the peak of significant wave height was $131^{\circ} \mathrm{N}$ and had a return period of 4 years. Instead, the storm that occurred between January and February 2014 reached a maximum significant wave height of $5.61 \mathrm{~m}$, lasted $140 \mathrm{~h}$, the direction at the peak of significant wave height was $114^{\circ} \mathrm{N}$ and had a return period of 7.5 years. The maximum significant wave height reached in this last storm is lower than the maximum significant wave height value observed in the last decade, which is $5.9 \mathrm{~m}$ (Table 1). This value was observed at the beginning of that decade and the sea storms after that of February 2014 reached maximum significant wave heights always lower than $5.5 \mathrm{~m}$. Furthermore, in all previous decades the observed maximum significant wave height values are higher than $5.9 \mathrm{~m}$. These considerations explain the low return period values obtained for each of the two sea storms analyzed.

Table 1. Wave climate characteristics in the various time intervals.

\begin{tabular}{cccc}
\hline Time Interval & $\mathbf{H}_{\mathbf{s}}$ Max $(\mathbf{m})$ & $\boldsymbol{\Phi}(\mathbf{N} / \mathbf{s})$ & Main Sector \\
\hline Entire & 6.67 & 6167 & 130 \\
$1980 \mathrm{~s}$ & 6.67 & 1598 & \\
$1990 \mathrm{~s}$ & 6.26 & 1679 & 1482 \\
$2000 \mathrm{~s}$ & 5.91 & 1407 & \\
$2010 \mathrm{~s}$ & 5.9 & & \\
\hline
\end{tabular}

Table 2. Characteristics of the sea storms that damaged the dune and the archaeological site.

\begin{tabular}{ccccccc}
\hline Sea Storm & Start & End & $\mathbf{H}_{\mathbf{s}}$ Max (m) & $\begin{array}{c}\text { Duration } \\
\text { (Hour) }\end{array}$ & $\begin{array}{c}\text { Peak Direction } \\
\text { Return Period } \\
\text { (Year) }\end{array}$ \\
\hline \multirow{2}{*}{2013} & $\begin{array}{c}29 \text { November } \\
5: 00 \text { PM }\end{array}$ & $\begin{array}{c}2 \text { December } \\
7: 00 \text { PM }\end{array}$ & 5.21 & 74 & 131 & 4 \\
2014 & 29 January & $\begin{array}{c}4 \text { February } \\
7: 00 \text { PM }\end{array}$ & 5.61 & 140 & 114 & 7.5 \\
\hline
\end{tabular}




\subsection{River Transport}

The analysis of river transport, in terms of average volume of detached soil due to surface erosion, was preceded by the perimeter and morphometric characterization of the Assi and Stilaro river basins. This phase has highlighted that the basins are bordering, and both have an elongated shape. Stilaro river, compared to the Assi river, has a greater area, about $100 \mathrm{~km}^{2}$ instead of over $65 \mathrm{~km}^{2}$, due to its greater width since the perimeters are almost the same, about $60 \mathrm{~km}$. The largest area is also correlated with a greater length of the tributaries, over $160 \mathrm{~km}$ instead of about $100 \mathrm{~km}$, while the main stream lengths are almost the same, about $30 \mathrm{~km}$. The average slope and the Horton order are also the same, $35 \%$ and 6 , respectively, while the average height and the Gravelius index are greater in the Assi river, about $700 \mathrm{~m}$ instead of about $600 \mathrm{~m}$ and 2 instead of 1.73, respectively. Finally, the time of concentration is greater in the Stilaro river, $4.3 \mathrm{~h}$ instead of $3.5 \mathrm{~h}$.

Regarding the rainfall time series, there are 11 rainfall and temperature gauges in the Assi and Stilaro River basin and in its neighboring areas, six of which are currently active. Among them, the Stilo-Ferdinandea thermo-pluviometric gauge has greater weight in both basins. Furthermore, for the Stilaro basin, also the Stignano gauge has significant weights while for the Assi basin the Santa Caterina dello Ionio gauge, for the rainfall, and the Monasterace-Punta Stilo gauge, for the temperature, have significant weights. The average weighted values of rainfall and temperature are, respectively, about $1260 \mathrm{~mm}$ and $14.4^{\circ} \mathrm{C}$ in the Stilaro basin and about $1300 \mathrm{~mm}$ and $13.4^{\circ} \mathrm{C}$ in the Assi basin.

Regarding land uses, there are 21 different uses. In both basins, the wooded and shrub areas are about $60 \%$, with a prevalence of holm oaks and beeches, while the agricultural areas are about $30 \%$, with a prevalence of olive groves. The weighted coefficients of soil protection, erodibility, and erosion are, respectively, $0.38,1.05$, and 0.34 in the Stilaro River basin and 0.36, 1.04, and 0.31 in the Assi River basin.

Finally, the average annual volume of eroded sediments is equal to over $60,000 \mathrm{~m}^{3} /$ year for the Stilaro basin and over 40,000 $\mathrm{m}^{3}$ /year for the Assi basin. Comparing these values to the areas of the two basins, it is observed that the specific erosion is almost the same for both basins, about $650 \mathrm{~m}^{3} /$ year* $\mathrm{km}^{2}$. This result is congruent with the evident hydrological, climatic, and land use similarities between the two basins.

\subsection{Shoreline Changes}

The analysis of the shoreline changes in the entire physiographic sub-unit between the Stilaro and Assi river mouths, shown in Table 3 and in Figure 5, highlighted that most of the erosive processes took place in the period between 1954 and 1989. Indeed, in 13 transepts out of 15 the maximum beach width dates back to 1954 and transepts 11 and 12 are exceptions whose maximum beach width dates back to 1989 .

In 1954, the beach widths have a maximum value of over $130 \mathrm{~m}$, a minimum value of over $40 \mathrm{~m}$, and an average value of about $85 \mathrm{~m}$. In 1989, on the other hand, the beach widths ranged from 30 to $70 \mathrm{~m}$, with an average value of about $50 \mathrm{~m}$. In this time interval, erosion between 10 and $95 \mathrm{~m}$ are observed, with an average value of $35 \mathrm{~m}$ and with relatively low speeds due to the considerable temporal extension of the interval. Both in 1954 and 1989 the maximum erosions are observed in the external transepts, located near the Stilaro and Assi river mouths. In terms of beach area, over $100,000 \mathrm{~m}^{2}$ were lost in this time interval.

Another significant erosive phase is observed between 1989 and 1996, with erosion in all transepts with values of the order of tens of meters up to a maximum of $45 \mathrm{~m}$ and with an average value of $17 \mathrm{~m}$. In 1996, the beach width was between 20 and $55 \mathrm{~m}$ approximately, with an average value of $32 \mathrm{~m}$ which is also the lowest value observed in the various years examined. In terms of beach area, about $60,000 \mathrm{~m}^{2}$ were lost in this time interval.

Regarding the subsequent time intervals, in the interval 1996-1998 the evolutionary trend is advancement, with a maximum value of about $15 \mathrm{~m}$ and an average value of $5 \mathrm{~m}$. Only the transepts near the mouth of the Stilaro river show slight erosion. In terms of beach area, there has been an increase of $20,000 \mathrm{~m}^{2}$ in this time interval. In the 1998-2000 interval, on the other hand, all the transepts are in slight advancement, with a maximum 
value of less than $10 \mathrm{~m}$ and an average value of $4 \mathrm{~m}$. In terms of beach area, there has been an increase of about $20,000 \mathrm{~m}^{2}$ in this time interval.

In these first four time intervals, the evolutionary trends are substantially homogeneous in the whole study area. Instead, in the new century, in each time interval analyzed, a very variable trend is observed along the various transepts.

Between 2000 and 2006 and between 2006 and 2008, erosive processes prevail. In the first time interval, the average value of the beach width increased by $2 \mathrm{~m}$ compared to the previous interval, but, in terms of beach area, about $5000 \mathrm{~m}^{2}$ were lost in this time interval. In the second time interval, the average value of beach width decreased by $8 \mathrm{~m}$ and, in terms of beach area, about $20,000 \mathrm{~m}^{2}$ were lost in this time interval.

Between 2008 and 2012 equilibrium conditions prevails. Indeed, eight transepts are advancing, and seven transepts are in erosion and the eroded areas are of the same order of magnitude as the increased ones.

Table 3. Beach area variations of each time interval. Legend: red = erosion; green = accretion; negative $=$ erosion; positive $=$ accretion .

\begin{tabular}{cccccccccccc}
\hline Time interval & $54-89$ & $89-96$ & $96-98$ & $98-00$ & $00-06$ & $06-08$ & $08-12$ & $12-14$ & $14-16$ & $16-17$ & $17-19$ \\
\hline Area $\left(\mathrm{m}^{3} \times 10^{3}\right)$ & -102 & -60 & 20 & 18 & -5 & -18 & 0 & 2 & -2 & 10 & 6 \\
\hline
\end{tabular}

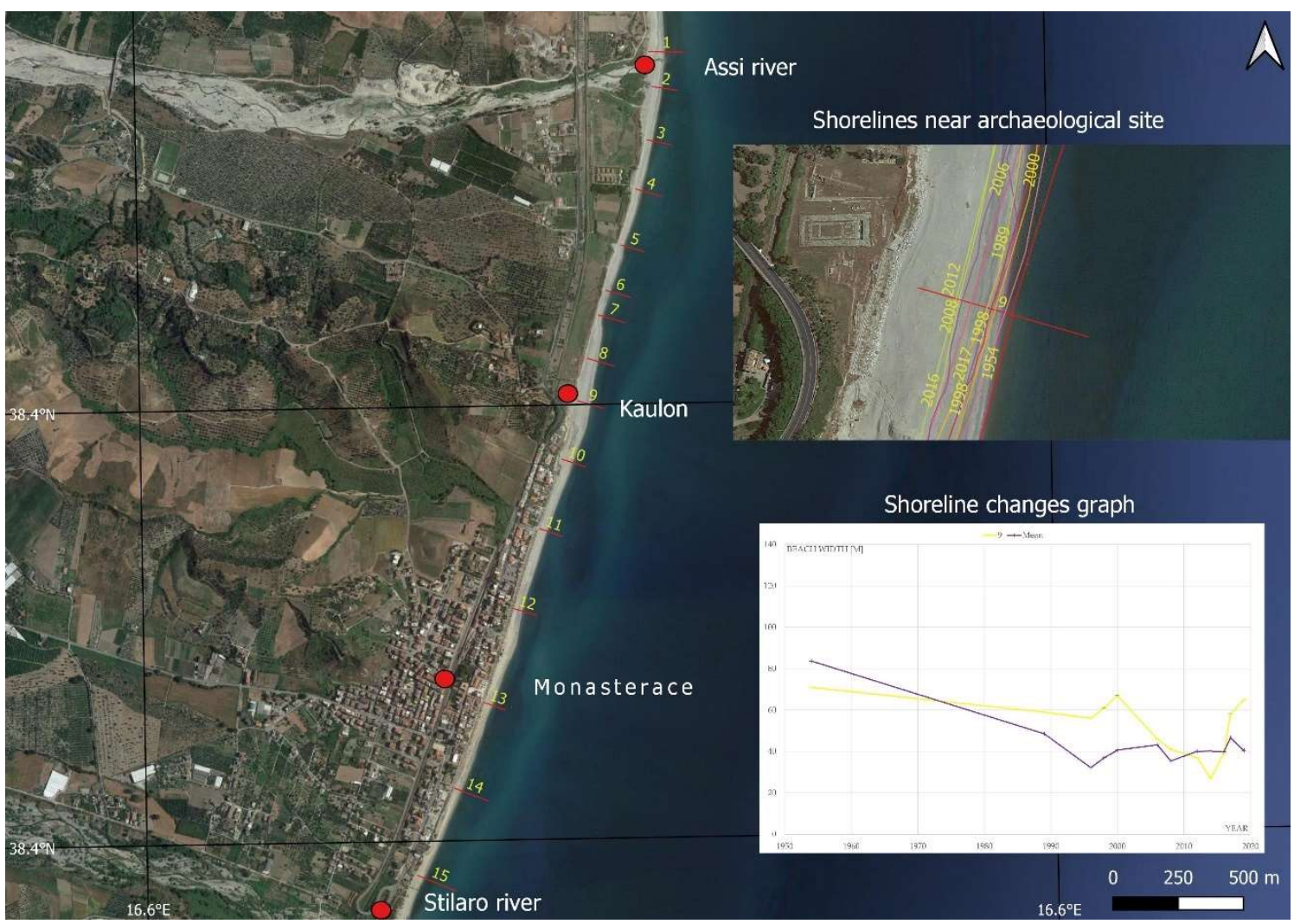

Figure 5. Large panel: analyzed transepts. Small panels: shorelines near the archaeological site (up) and graph of the shoreline changes in the transept at the archaeological site, yellow line, and of the average changes in all analyzed transepts, purple line (down).

Between 2012 and 2014 and between 2014 and 2016, the global evolutionary trend would seem to be in equilibrium, as the variation of the beach width is equal to 0 in both intervals. Additionally, in terms of beach area, there has been an increase of only $1000 \mathrm{~m}^{2}$ in the first time interval and an erosion of only $1000 \mathrm{~m}^{2}$ in the second time interval. However, by analyzing the individual transepts, it is observed that between 2012 and 2014 
seven transepts are in erosion, with a maximum value exceeding $10 \mathrm{~m}$, seven transepts are advancing, with a maximum value of about $30 \mathrm{~m}$, and only one transept is stable. Between 2014 and 2016 seven transepts are in erosion, with a maximum value of about $20 \mathrm{~m}$, seven transepts are advancing, with a maximum value exceeding $15 \mathrm{~m}$, and only one transept is stable. Therefore, in these time intervals the solid material has spatially redistributed between the various transepts and the transepts where the greatest variations are observed in the external ones, located at the Stilaro and Assi rivers mouths.

Between 2016 and 2017, on the other hand, advancement processes prevail, with an average value of $7 \mathrm{~m}$ and, in terms of beach area, there has been an increase of $10,000 \mathrm{~m}^{2}$ in this time interval.

Instead, between 2017 and 2019 erosive processes prevail again with an average erosion of $7 \mathrm{~m}$ and, in terms of beach area, there has been an erosion of over $5000 \mathrm{~m}^{2}$. Additionally, it should be noted that the most recent average beach width is the same as in 2000 and less than half than that of 1954.

Finally, by analyzing the evolutionary trends of transept 9 , located in front of the archaeological site, erosion is observed up to 1996, with a value equal to $15 \mathrm{~m}$, then advancement is observed up to 2000 of a value equal to $10 \mathrm{~m}$. Subsequently, an erosive process begins, the maximum of which occurs in 2014, with a value of $40 \mathrm{~m}$ and with an erosion than $30 \mathrm{~m}$. From 2014 to 2019, the beach advances and the most recent width is just over $70 \mathrm{~m}$, the same value as in 1954 .

\subsection{Dune System Damage}

The archaeological site was damaged by two sea storms, both of which occurred in the winter of 2013-2014. The first storm that occurred in early December 2013, eroded much of the beach below the archaeological site and caused the partial collapse of the dune, with the sliding of some archaeological finds into the beach below (Figure 6a). After this sea storm, in early February 2014 another sea storm caused further damage to the dune and to the archaeological site (Figure 6b). These damages are like those observed after the first storm but did not cause significant retreat of the dune system. Following the sea storm of December 2013, the Provincial Administration of Reggio Calabria financed in urgency the construction of a barrier. The barrier has a trapezoidal shape, is $3 \mathrm{~m}$ in height, $6 \mathrm{~m}$ in width, and $30 \mathrm{~m}$ long, and was built on the beach a few meters from the sea, at about $8 \mathrm{~m}$ from the dune. The height between the ground level and the top of the barrier is $1.5 \mathrm{~m}$ (Figure 7a). This barrier, however, represents a temporary intervention, with limited effectiveness as it is much shorter than the entire dune to be protected and as the sea storms crossed it (Figure 7b) as occurred during the storm of February 2014. To solve these problems, an intervention extended to the entire archaeological site was carried out between 2017 and 2019 (Figure 8b). In detail, a barrier was built at the foot of the dune that protects the dune from the direct action of sea storms and reduces the erosion on the foot. Up to now, this intervention has effectively protected the beach-dune system.

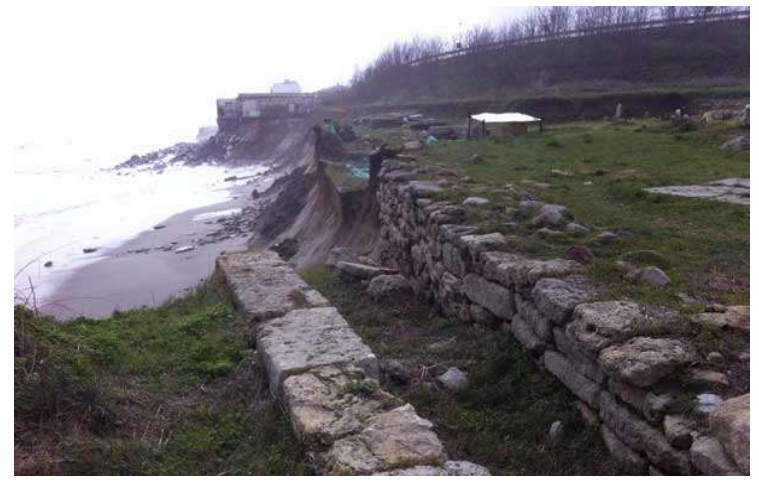

(a)

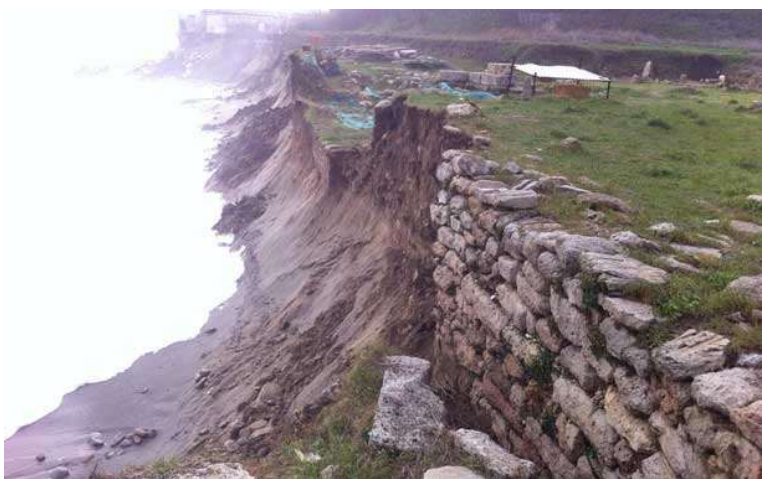

(b)

Figure 6. Doric Temple. (a) After the December 2013 storm. (b) After the February 2014 storm. 


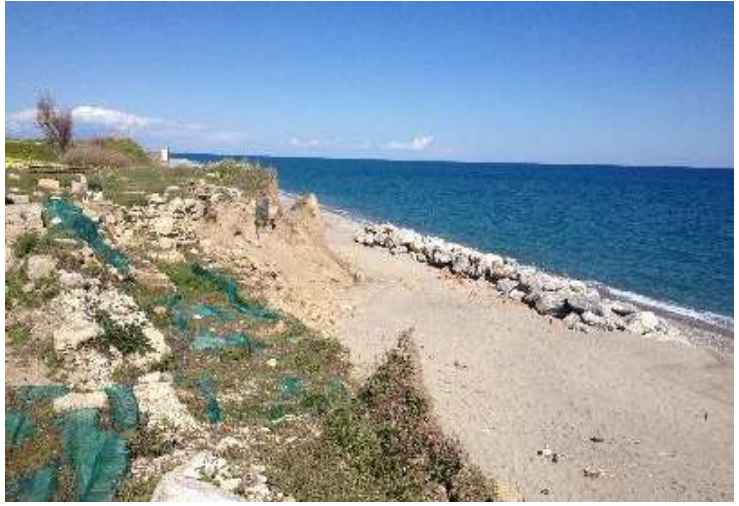

(a)

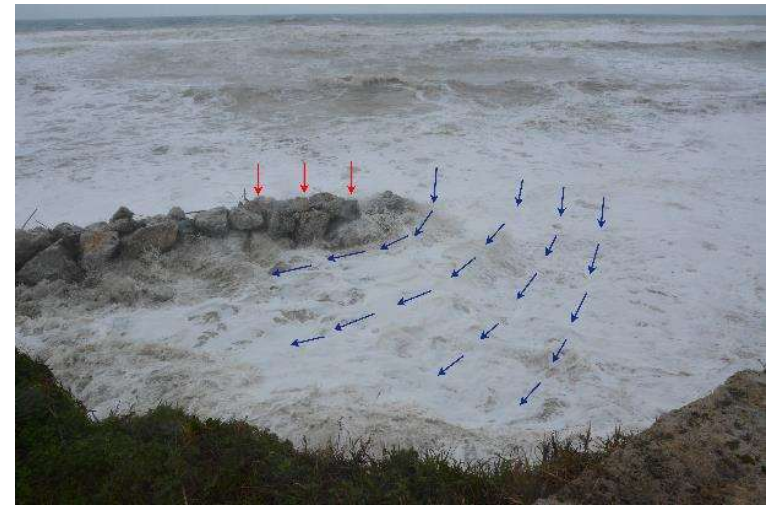

(b)

Figure 7. (a) Barrier made in January 2014. (b) Storm of February 2014 (blue arrows) that crosses the barrier (red arrows).

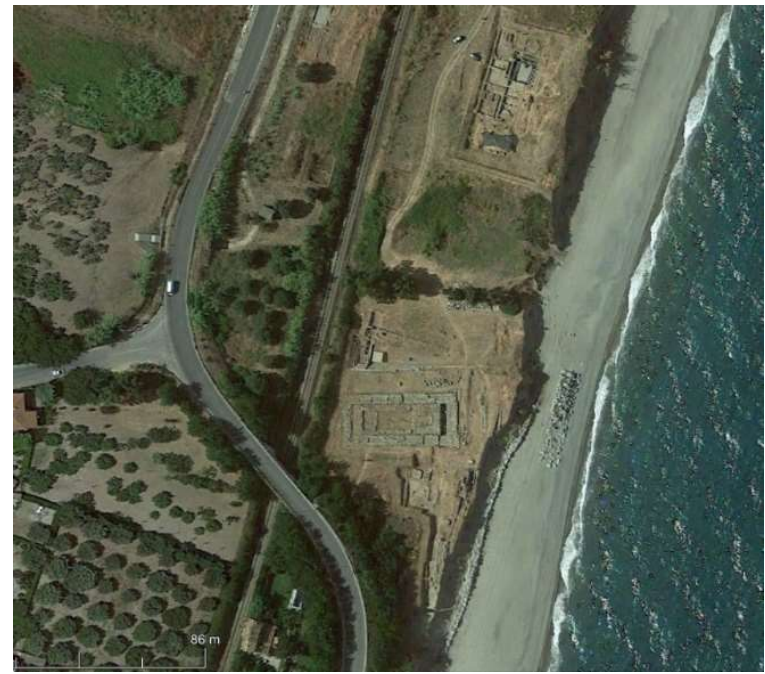

(a)

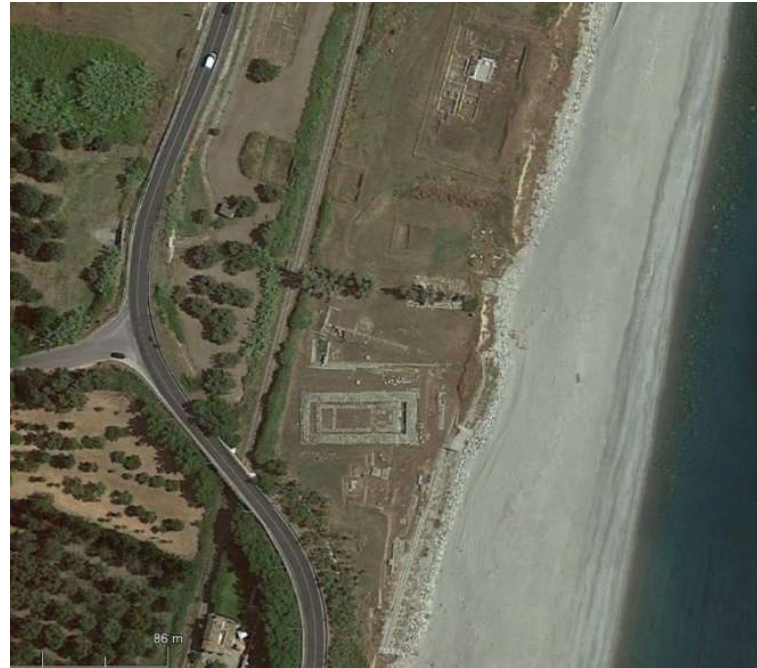

(b)

Figure 8. (a) Google satellite image of 2014 (scale 1:1000, North oriented). (b) Google satellite image of 2019 (scale 1:1000, North oriented).

\section{Discussion}

To evaluate the effects produced by the three examined erosive factors, which are anthropogenic pressure, wave climate, and sea storms and river transport, the shoreline changes and the damage to the dune system were analyzed, also evaluating the effectiveness of the defense interventions. The main causes of the erosive processes were identified through the cross analysis of erosive factors and their effects.

The analysis of the shoreline changes has shown that most of the erosive processes in the study area are concentrated between 1954 and 1996. In this period, the inhabited center of Monasterace has considerably expanded and buildings and a promenade have been built instead of large beach areas. Similar situations have also been observed in many other Calabrian territories. Anthropogenic pressure has not affected only the coastal areas but also many rivers. Indeed, from the 60s of the last century up to the 90s, numerous weirs were built in most of the Calabrian rivers following disastrous floods. Among the effects produced by them, it should be mentioned the immobilization of significant quantities of sediments, which have reduced the river transport. In the study area, the greatest shoreline retreats between 1954 and 1996 have been observed at the Assi and Stilaro river mouths and at the inhabited center. Therefore, the erosive processes observed between 1954 and 1996 are mainly related to anthropogenic factors. 
In the last 25 years, there has been an alternation between erosions and accretions, and the current average beach width is the same as in 2000 and less than half than that of 1954. Instead, by moving the analysis scale from the entire sub-unit to the single transepts, a homogeneous trend is observed in line with the global one up to 2000. After, the trend becomes very variable even in the time intervals where the average variation of the beach area is nothing or small. The situation that in the same time interval there are transepts in erosion and in advancement, but with zero or small variations in the total area of the beach, highlights that the sediments are redistributed within the sub-unit. Additionally, in this time interval, no significant anthropogenic interventions were observed along coasts and rivers of the study area. Therefore, anthropogenic pressure does not appear to be the cause of these evolutionary trends, so to identify the possible causes of this phenomenon, natural factors were analyzed, especially the balance between longshore and river sediment transport. In detail, the mean longshore transport estimated with the Tomasicchio et al. [78] model is about $90,000 \mathrm{~m}^{3}$ /year and is directed from South to North so the Stilaro River would be the main source of sediment for the study area. However, this area is also subject to sea storms from the North-East directions, so the Assi River is also a source of sediments. The mean river transport, estimated with the Gavrilovic model [80], is over $60,000 \mathrm{~m}^{3}$ /year for the Stilaro River and over 40,000 $\mathrm{m}^{3}$ /year for the Assi River. Globally, the river contribution afferent to the examined physiographic sub-unit is approximately $100,000 \mathrm{~m}^{3}$ /year. Therefore, longshore and river transport are on average of the same magnitude. This consideration allows us to hypothesize that the evolutionary trend of the last 25 years is mainly related to natural factors that alter the sedimentary balance, such as the action of single sea storms or particularly rainy or dry periods. Regarding the latter parameter, this hypothesis is also reinforced by the following considerations: the river sediment transport is mainly related to WSE, significant anthropic interventions are absent, and the sediments are redistributed along the study area, and the greatest variations are observed in the external transepts, near the Stilaro and Assi river mouths.

Regarding the damage to the dune system, the sea storms that occurred in the winter of 2013-2014 were analyzed. These storms occurred when the beach width was very small. From a statistical point of view, the two sea storms had return periods of 4 and 7.5 years, therefore corresponding to statistically frequent events. Between the two sea storms, the one that most damaged the coast was the second as it was characterized by a long duration, $140 \mathrm{~h}$, and coming from almost orthogonal directions with respect to the coast itself. Therefore, these sea storms are not extreme events, so the damage is probably related to the action of each sea storm and is accentuated from the fact that these events occurred when the beach width was a few tens of meters, much lower than that observed in the other time intervals analyzed. The storms of winter 2013-2014 did not only affect the coast of Monasterace but also affected several locations in Western Europe causing beach and dune erosion [46,54]. In summary, the main causes of the erosive processes of the dune-beach system are anthropic in the last century and natural in the new century.

Finally, after analyzing the main causes of erosive processes, the effectiveness of two different interventions was analyzed. The first intervention is a barrier that was built in urgency between the two sea storms and was located on the beach between the shoreline and the dune. This barrier, however, represents a temporary intervention, with limited effectiveness as the sea storms crossed it (Figure 7b) as occurred during the storm of February 2014. Furthermore, the barrier has a length of $30 \mathrm{~m}$ while the archaeological site has a length of over $250 \mathrm{~m}$ so that a significant portion of the dune has remained unprotected (Figure 8a). Instead, the barrier built after 2017 was located close to the dune and extends the entire dune length. Thus, the problem of the wave motion crossing was solved, and the entire dune was protected. The validity of this intervention is highlighted by the fact that after its realization no further damage was reported. Instead, temporary and urgent interventions such as the one at the beginning of 2014 often are not very effective. 


\section{Conclusions}

The paper, through a case study concerns the archaeological site of Kaulon, located on a dune in the Ionian coast of Calabria (Italy), analyzed the beach and dune erosive processes, their causes, and possible interventions.

The methodology proposed in this paper does not focus on a single erosive factor but evaluates the effects caused by three main factors on the beach-dune system. These factors are anthropogenic pressure, wave climate, and sea storms and river transport. On the other hand, the effects were assessed in terms of shoreline changes and damage to the dune system.

The analysis of the shoreline evolutionary trends carried out at a physiographic subunit scale highlighted a possible correlation between erosive processes and anthropogenic pressures in the second half of the last century. On the other hand, in the new century the evolutionary trends are mainly correlated to natural factors. Among the natural factors, the most relevant were the sea storms of winter 2013-2014 which damaged the archaeological site. River transport is also relevant both due to the peculiarities of the Calabrian rivers and due to the shoreline changes observed near the Assi and Stilaro river mouths.

In addition to this analysis, the effects produced by the construction of two interventions to protect the dune and the archaeological site were also evaluated. In detail, a barrier of modest width was initially built, located in the stretch of beach between the dune and the shoreline. Subsequently, a barrier was built at the foot of the dune, which extends along the entire length of the archaeological site.

However, the initial barrier did not serve to protect the dune itself which, on the contrary, was more damaged by the second storm and the wave motion bypassed the barrier itself. Instead, the barrier at the foot of the dune that extends along the entire length of the archaeological site seems to be a suitable intervention to protect the archaeological site from the action of sea storms as evidenced by the absence of new damage from its construction to date.

Finally, the analysis described in the paper highlighted how temporary interventions, often punctual and carried out in urgency, are not resolutive of the erosive problem but, instead, can accentuate it. Therefore, extended interventions, that consider the causes of erosive phenomena, are more suitable. This analysis is of interest for the protection and management of coastal areas and can be easily replicated in any location as it requires free access data and uses free access software and models present in scientific literature and characterized by ease of application.

Author Contributions: Conceptualization, G.B.; methodology, G.B., G.F., G.C.B. and F.F.; software, G.F. and G.C.B.; validation, G.B., G.F., G.C.B. and F.F.; formal analysis, G.F. and G.C.B.; investigation, G.F. and G.C.B.; resources, G.F. and G.C.B.; data curation, G.F. and G.C.B.; writing-original draft preparation, G.F.; writing - review and editing, G.B., G.F., G.C.B. and F.F.; visualization, G.F.; supervision, G.B.; project administration, G.B. All authors have read and agreed to the published version of the manuscript.

Funding: This research received no external funding.

Institutional Review Board Statement: Not applicable.

Informed Consent Statement: Not applicable.

Acknowledgments: Part of this work was carried out within the SIMONA Project (Systems and technologies for the monitoring of cultural areas in underwater and terrestrial environment, POR Calabria 2007/2013). Furthermore, the authors thank Giovanni Besio for providing the wave data of the MeteOcean database.

Conflicts of Interest: The authors declare no conflict of interest. 


\section{References}

1. Fryberger, S.G.; Dean, G. Dune forms and wind regime. In A Study of Global Sand Seas; McKee, E.D., Ed.; United States Geological Survey Professional Paper; US Government Printing Office: Washington, DC, USA, 1979; Volume 1052, pp. 137-169.

2. Jay, H. Beach-Dune Sediment Exchange and Morphodynamic Responses: Implications for Shoreline Management, the Sefton Coast, NW England. Ph.D. Thesis, University of Reading, Reading, UK, 1998.

3. Sabatier, F.; Anthony, E.J.; Héquette, A.; Suanez, S.; Musereau, J.; Ruz, M.-H.; Regnauld, H. Morphodynamics of beach/dune systems: Examples from the coast of France. Géomorphol. Relief Processus Environ. 2009, 15, 3-22. [CrossRef]

4. Harley, M.; Ciavola, P. Managing local coastal inundation risk using real-time forecasts and artificial dune placements. Coast. Eng. 2013, 77, 77-90. [CrossRef]

5. Luijendijk, A.; Hagenaars, G.; Ranasinghe, R.; Baart, F.; Donchyts, G.; Aarninkhof, S. The State of the World's Beaches. Sci. Rep. 2018, 8, 6641. [CrossRef] [PubMed]

6. Mentaschi, L.; Vousdoukas, M.I.; Pekel, J.-F.; Voukouvalas, E.; Feyen, L. Global long-term observations of coastal erosion and accretion. Sci. Rep. 2018, 8, 12876. [CrossRef] [PubMed]

7. Vousdoukas, M.I.; Ranasinghe, R.; Mentaschi, L.; Plomaritis, T.A.; Athanasiou, P.; Luijendijk, A.; Feyen, L. Sandy coastlines under threat of erosion. Nat. Clim. Chang. 2020, 10, 260-263. [CrossRef]

8. European Commission. Article 17 Technical Report 2001-2006; European Topic Centre on Biological Diversity. 2008. Available online: https:/ / ec.europa.eu/environment/nature/knowledge/rep_habitats/index_en.htm\#heading2001/06 (accessed on 20 October 2021).

9. Pye, K. Physical and human influences on coastal dune development between the Ribble and Mersey estuaries, Northwest England. In Coastal Dunes: Processes and Morphology; Nordstrom, K.F., Psuty, N.P., Carter, R.W.G., Eds.; Wiley: Chichester, UK, 1990; pp. 339-359.

10. Sancho, F.; Abreu, T.; D’Alessandro, F.; Tomasicchio, G.R.; Silva, P.A. Surf hydrodynamics under collapsing coastal dunes. J. Coast Res. 2011, 64, 144-148.

11. Anthony, E.J. Storms, shoreface morphodynamics, sand supply, and the accretion and erosion of coastal dune barriers in the southern North Sea. Geomorphology 2013, 199, 8-21. [CrossRef]

12. Feagin, R.; Furman, M.; Salgado, K.; Martinez, M.; Innocenti, R.; Eubanks, K.; Figlus, J.; Huff, T.; Sigren, J.; Silva, R. The role of beach and sand dune vegetation in mediating wave run up erosion. Estuar. Coast. Shelf Sci. 2019, 219, 97-106. [CrossRef]

13. Pye, K.; Blott, S. Decadal-scale variation in dune erosion and accretion rates: An investigation of the significance of changing storm tide frequency and magnitude on the Sefton coast, UK. Geomorphology 2008, 102, 652-666. [CrossRef]

14. Swann, C.; Bride, K.; Spore, N. Coast Foredunes: Identifying Coastal, Aeolian and Management Interactions Driving Morphological State Change; ERDC/CHL TR-17873; U.S. Army Corps of Engineers: Washington, DC, USA, 2014.

15. Walker, I.J.; Davidson-Arnott, R.G.D.; Bauer, B.O.; Hesp, P.A.; Delgado-Fernandez, I.; Ollerhead, J.; Smyth, T.A.G. Scale-dependent perspectives on the geomorphology and evolution of beach-dune systems. Earth-Sci. Rev. 2017, 171, 220-253. [CrossRef]

16. Tomasicchio, G.R.; Francone, A.; Simmonds, D.J.; D'Alessandro, F.; Frega, F. Prediction of Shoreline Evolution. Reliability of a General Model for the Mixed Beach Case. J. Mar. Sci. Eng. 2020, 8, 361. [CrossRef]

17. Miduri, M.; Foti, G.; Puntorieri, P. Impact generated by Marina of Badolato on adjacent coasts. In Proceedings of the 13th International Congress on Coastal and Marine Sciences, Engineering, Management \& Conservation (MEDCOAST), Mellieha, Malta, 31 October-4 November 2017; Volume 2, pp. 935-945.

18. Zema, D.A.; Bombino, G.; Boix-Fayos, C.; Tamburino, V.; Zimbone, S.M.; Fortugno, D. Evaluation and modeling of scouring and sedimentation around check dams in a Mediterranean torrent in Calabria, Italy. J. Soil Water Conserv. 2014, 69, 316-329. [CrossRef]

19. Foti, G.; Barbaro, G.; Manti, A.; Foti, P.; La Torre, A.; Geria, P.F.; Puntorieri, P.; Tramontana, N. A methodology to evaluate the effects of river sediment withdrawal: The case study of the Amendolea River in southern Italy. Aquat. Ecosyst. Health Manag. 2020, 23, 465-473. [CrossRef]

20. Dissanayake, P.; Brown, J.; Karunarathna, H. Impacts of storm chronology on the morphological changes of the Formby beach and dune system, UK. Nat. Hazards Earth Syst. Sci. 2015, 15, 1533-1543. [CrossRef]

21. Splinter, K.D.; Carley, J.T.; Golshani, A.; Tomlinson, R. A relationship to describe the cumulative impact of storm clusters on beach erosion. Coast. Eng. 2014, 83, 49-55. [CrossRef]

22. Dissanayake, P.; Brown, J.; Wisse, P.; Karunarathna, H. Comparison of storm cluster vs isolated event impacts on beach/dune morphodynamics. Estuar. Coast. Shelf Sci. 2015, 164, 301-312. [CrossRef]

23. Wernette, P.; Houser, C.; Lehner, J.; Evans, A.; Weymer, B. Investigating the Impact of Hurricane Harvey and Driving on Beach-Dune Morphology. Geomorphology 2020, 358, 107119. [CrossRef]

24. Barbaro, G.; Petrucci, O.; Canale, C.; Foti, G.; Mancuso, P.; Puntorieri, P. Contemporaneity of Floods and Storms. A Case Study of Metropolitan Area of Reggio Calabria in Southern Italy. In New Metropolitan Perspectives. ISHT 2018. Smart Innovation, Systems and Technologies; Springer: Cham, Switzerland, 2019; Volume 101, pp. 614-620. [CrossRef]

25. Canale, C.; Barbaro, G.; Foti, G.; Petrucci, O.; Besio, G.; Barillà, G.C. Bruzzano river mouth damage due to meteorological events. Int. J. River Basin Manag. 2021, 1-17. [CrossRef]

26. Canale, C.; Barbaro, G.; Petrucci, O.; Fiamma, V.; Foti, G.; Barillà, G.C.; Puntorieri, P.; Minniti, F.; Bruzzaniti, L. Analysis of floods and storms: Concurrent conditions. Ital. J. Eng. Geol. Environ. 2020, 1, 23-29. [CrossRef] 
27. Barbaro, G.; Foti, G.; Nucera, A.; Barillà, G.C.; Canale, C.; Puntorieri, P.; Minniti, F. Risk mapping of coastal flooding areas. Case studies: Scilla and Monasterace (Italy). Int. J. Saf. Secur. Eng. 2020, 10, 59-67. [CrossRef]

28. Castelle, B.; Marieu, V.; Bujan, S.; Splinter, K.D.; Robinet, A.; Sénéchal, N.; Ferreira, S. Impact of the winter 2013-2014 series of severe Western Europe storms on a double-barred sandy coast: Beach and dune erosion and megacusp embayments. Geomorphology 2015, 238, 135-148. [CrossRef]

29. Houser, C. Alongshore variation in the morphology of coastal dunes: Implications for storm response. Geomorphology 2013, 199, 48-61. [CrossRef]

30. de Winter, R.; Gongriep, F.; Ruessink, B. Observations and modeling of alongshore variability in dune erosion at Egmond aan Zee, The Netherlands. Coast. Eng. 2015, 99, 167-175. [CrossRef]

31. Pye, K.; Neal, A. Coastal dune erosion at Formby Point, north Merseyside, England: Causes and Mechanisms. Mar. Geol. 1994, 119, 39-56. [CrossRef]

32. Molina, R.; Manno, G.; Re, C.L.; Anfuso, G. Dune Systems' Characterization and Evolution in the Andalusia Mediterranean Coast (Spain). Water 2020, 12, 2094. [CrossRef]

33. van Thiel de Vries, J.S.M.; Van Gent, M.R.A.; Walstra, D.J.R.; Reniers, A.J.H.M. Analysis of dune erosion processes in large-scale flume experiments. Coast. Eng. 2008, 55, 1028-1040. [CrossRef]

34. Tomasicchio, G.R.; D'Alessandro, F.; Barbaro, G. Composite modelling for large-scale experiments on wave-dune interaction. J. Hydraul. Res. 2011, 49, 15-19. [CrossRef]

35. Tomasicchio, G.R.; Sánchez-Arcilla, A.; D’Alessandro, F.; Ilic, S.; James, M.R.; Sancho, F.; Fortes, C.J.; Schüttrumpf, H. Large-scale experiments on dune erosion processes. J. Hydraul. Res. 2011, 49, 20-30. [CrossRef]

36. D'Alessandro, F.; Tomasicchio, G.R. Wave-dune interaction and beach resilience in large-scale physical model tests. Coast. Eng. 2016, 116, 15-25. [CrossRef]

37. Palmsten, M.; Splinter, K.D. Observations and simulations of wave runup during a laboratory dune erosion experiment. Coast. Eng. 2016, 115, 58-66. [CrossRef]

38. Larson, M.; Erikson, L.; Hanson, H. An analytical model to predict dune erosion due to wave impact. Coast. Eng. 2004, 51, 675-696. [CrossRef]

39. Roelvink, D.; Reniers, A.; Van Dongeren, A.; De Vries, J.V.T.; McCall, R.; Lescinski, J. Modelling storm impacts on beaches, dunes and barrier islands. Coast. Eng. 2009, 56, 1133-1152. [CrossRef]

40. D'Alessandro, F.; Tomasicchio, G.R.; Musci, F.; Ricca, A. Dune erosion physical, analytical and numerical modelling. In Proceedings of the 33rd International Conference on Coastal Engineering, Santander, Spain, 1-6 July 2012. [CrossRef]

41. Esteves, L.S.; Brown, J.M.; Williams, J.J.; Lymbery, G. Quantifying thresholds for significant dune erosion along the Sefton Coast, Northwest England. Geomorphology 2012, 143-144, 52-61. [CrossRef]

42. Li, F.; van Gelder, P.; Vrijling, J.; Callaghan, D.; Jongejan, R.; Ranasinghe, R. Probabilistic estimation of coastal dune erosion and recession by statistical simulation of storm events. Appl. Ocean Res. 2014, 47, 53-62. [CrossRef]

43. Furmańczyk, K.; Dudzińska-Nowak, J.; Paplińska-Swerpel, B.; Brzezowska, N.; Furmańczyk, K. Critical storm thresholds for the generation of significant dune erosion at Dziwnow Spit, Poland. Geomorphology 2012, 143-144, 62-68. [CrossRef]

44. Tătui, F.; Vespremeanu-Stroe, A.; Preoteasa, L. Alongshore variations in beach-dune system response to major storm events on the Danube Delta coast. J. Coast. Res. 2014, 70, 693-699. [CrossRef]

45. Saye, S.E.; van der Wal, D.; Pye, K.; Blott, S.J. Beach-dune morphological relationships and erosion/accretion: An investigation at five sites in England and Wales using LIDAR data. Geomorphology 2005, 72, 128-155. [CrossRef]

46. Pye, K.; Blott, S.J. Assessment of beach and dune erosion and accretion using LiDAR: Impact of the stormy 2013-14 winter and longer term trends on the Sefton Coast, UK. Geomorphology 2016, 266, 146-167. [CrossRef]

47. Lerma, A.N.; Ayache, B.; Ulvoas, B.; Paris, F.; Bernon, N.; Bulteau, T.; Mallet, C. Pluriannual beach-dune evolutions at regional scale: Erosion and recovery sequences analysis along the aquitaine coast based on airborne LiDAR data. Cont. Shelf Res. 2019, 189, 103974. [CrossRef]

48. Pagán, J.I.; Bañón, L.; López, I.; Bañón, C.; Aragonés, L. Monitoring the dune-beach system of Guardamar del Segura (Spain) using UAV, SfM and GIS techniques. Sci. Total Environ. 2019, 687, 1034-1045. [CrossRef]

49. Andriolo, U.; Gonçalves, G.; Sobral, P.; Fontán-Bouzas, Á.; Bessa, F. Beach-dune morphodynamics and marine macro-litter abundance: An integrated approach with Unmanned Aerial System. Sci. Total. Environ. 2020, 749, 141474. [CrossRef] [PubMed]

50. D'Alessandro, F.; Tomasicchio, G.R.; Frega, F.; Carbone, M. Design and management aspects of a coastal protection system. A case history in the South of Italy. J. Coast. Res. 2011, 64, 492-495.

51. van Rijn, L. Coastal erosion and control. Ocean Coast. Manag. 2011, 54, 867-887. [CrossRef]

52. Suanez, S.; Cariolet, J.-M.; Cancouët, R.; Ardhuin, F.; Delacourt, C. Dune recovery after storm erosion on a high-energy beach: Vougot Beach, Brittany (France). Geomorphology 2012, 139-140, 16-33. [CrossRef]

53. Scott, T.; Masselink, G.; O'Hare, T.; Saulter, A.; Poate, T.; Russell, P.; Davidson, M.; Conley, D. The extreme 2013/2014 winter storms: Beach recovery along the southwest coast of England. Mar. Geol. 2016, 382, 224-241. [CrossRef]

54. Castelle, B.; Bujan, S.; Ferreira, S.; Dodet, G. Foredune morphological changes and beach recovery from the extreme $2013 / 2014$ winter at a high-energy sandy coast. Mar. Geol. 2017, 385, 41-55. [CrossRef]

55. Smith, E.R.; D'Alessandro, F.; Tomasicchio, G.R.; Gailani, J.Z. Nearshore placement of a sand dredged mound. Coast. Eng. 2017, 126, 1-10. [CrossRef] 
56. Williams, A.; Rangel-Buitrago, N.; Pranzini, E.; Anfuso, G. The management of coastal erosion. Ocean Coast. Manag. 2018, 156, 4-20. [CrossRef]

57. Bazzichetto, M.; Sperandii, M.; Malavasi, M.; Carranza, M.; Acosta, A. Disentangling the effect of coastal erosion and accretion on plant communities of Mediterranean dune ecosystems. Estuar. Coast. Shelf Sci. 2020, 241, 106758. [CrossRef]

58. D’Alessandro, F.; Tomasicchio, G.R.; Francone, A.; Leone, E.; Frega, F.; Chiaia, G.; Saponieri, A.; Damiani, L. Coastal sand dune restoration with an eco-friendly technique. Aquat. Ecosyst. Health Manag. 2020, 417-426. [CrossRef]

59. Fernández-Montblanc, T.; Duo, E.; Ciavola, P. Dune reconstruction and revegetation as a potential measure to decrease coastal erosion and flooding under extreme storm conditions. Ocean Coast. Manag. 2020, 188, 105075. [CrossRef]

60. Leone, E.; Kobayashi, N.; Francone, A.; Bartolo, S.; Strafella, D.; D’Alessandro, F.; Tomasicchio, G. Use of Nanosilica for Increasing Dune Erosion Resistance during a Sea Storm. J. Mar. Sci. Eng. 2021, 9, 620. [CrossRef]

61. Cohn, N.; Brodie, K.L.; Johnson, B.; Palmsten, M.L. Hotspot dune erosion on an intermediate beach. Coast. Eng. 2021, 170, 103998. [CrossRef]

62. Baldock, T.; Gravois, U.; Callaghan, D.; Davies, G.; Nichol, S. Methodology for estimating return intervals for storm demand and dune recession by clustered and non-clustered morphological events. Coast. Eng. 2021, 168, 103924. [CrossRef]

63. Cohn, N.; Ruggiero, P.; García-Medina, G.; Anderson, D.; Serafin, K.A.; Biel, R. Environmental and morphologic controls on wave-induced dune response. Geomorphology 2019, 329, 108-128. [CrossRef]

64. Dissanayake, P.; Brown, J.; Sibbertsen, P.; Winter, C. Using a two-step framework for the investigation of storm impacted beach/dune erosion. Coast. Eng. 2021, 168, 103939. [CrossRef]

65. Hird, S.; Stokes, C.; Masselink, G. Emergent coastal behaviour results in extreme dune erosion decoupled from hydrodynamic forcing. Mar. Geol. 2021, 442, 106667. [CrossRef]

66. Sanromualdo-Collado, A.; García-Romero, L.; Peña-Alonso, C.; Hernández-Cordero, A.I.; Ferrer-Valero, N.; Hernández-Calvento, L. Spatiotemporal analysis of the impact of artificial beach structures on biogeomorphological processes in an arid beach-dune system. J. Environ. Manag. 2021, 282, 111953. [CrossRef]

67. Barbaro, G.; Foti, G.; Sicilia, C.L. Erosive Phenomena in the Proximity of Kaulon Archaeological Park: Origins and Remedies. Procedia Soc. Behav. Sci. 2016, 223, 714-719. [CrossRef]

68. Barbaro, G.; Foti, G.; Sicilia, C.L. Fenomeni erosivi in prossimità del parco archeologico di kaulon (RC): Cause e rimedi. LaborEst 2016, 12, 75-79. [CrossRef]

69. Mandaglio, M.C.; Gioffrè, D.; Pitasi, A.; Moraci, N. Qualitative Landslide Susceptibility Assessment in Small Areas. Procedia Eng. 2016, 158, 440-445. [CrossRef]

70. Calabria Region. Indagine Conoscitiva Dello Stato Delle COSTE Calabresi, predisposizione di una Banca Dati Dell'evoluzione del Litorale e Individuazione Delle Aree a Rischio e Delle Tipologie di Intervento. Studi su Aree Campione e Previsione Delle RELATIVE opere di Difesa; Final Report; Calabria Region: Catanzaro, Italy, 2003. (In Italian)

71. Sabato, L.; Tropeano, M. Fiumara: A kind of high hazard river. Phys. Chem. Earth Parts A/B/C 2004, 29, 707-715. [CrossRef]

72. Sorriso-Valvo, M.; Terranova, O. The Calabrian fiumara streams. Z. Für Geomorphol. 2006, 143, 109-125.

73. Barbaro, G.; Foti, G.; Mandaglio, G.; Mandaglio, M.; Sicilia, C.L. Estimate of sediment transport capacity in the basin of the Fiumara Annunziata (RC). In Proceedings of the Atti del $86^{\circ}$ Congresso Nazionale della Società Geologica Italiana, Arcavacata di Rende (CS), Italy, 18-20 September 2012; Volume 21, pp. 696-697.

74. Terranova, O.; Antronico, L.; Coscarelli, R.; Iaquinta, P. Soil erosion risk scenarios in the Mediterranean environment using RUSLE and GIS: An application model for Calabria (southern Italy). Geomorphology 2009, 112, 228-245. [CrossRef]

75. Barbaro, G.; Bombino, G.; Foti, G.; Borrello, M.M.; Puntorieri, P. Shoreline evolution near river mouth: Case study of Petrace River (Calabria, Italy). Reg. Stud. Mar. Sci. 2019, 29, 100619. [CrossRef]

76. Foti, G.; Barbaro, G.; Bombino, G.; Fiamma, V.; Puntorieri, P.; Minniti, F.; Pezzimenti, C. Shoreline changes near river mouth: Case study of Sant'Agata River (Reggio Calabria, Italy). Eur. J. Remote Sens. 2019, 52, 102-112. [CrossRef]

77. Stockdon, H.F.; Holman, R.A.; Howd, P.A.; Sallenger, A.H. Empirical parameterization of setup, swash, and runup. Coast. Eng. 2006, 53, 573-588. [CrossRef]

78. Istituto Idrografico della Marina. Tavole di Marea e Delle Correnti di Marea; Istituto Idrografico della Marina Italiana: Genova, Italy, 2020; p. 144. ISBN 97888II3133. (In Italian)

79. Sannino, G.; Carillo, A.; Pisacane, G.; Naranjo, C. On the relevance of tidal forcing in modelling the Mediterranean thermohaline circulation. Prog. Oceanogr. 2015, 134, 304-329. [CrossRef]

80. Bretschneider, C.L. Engineering aspects of hurricane surge. In Estuary and Coastline Hydrodynamics; Ippen, A.T., Ed.; McGraw-Hill: New York, NY, USA, 1966.

81. Tomasicchio, G.R.; D’Alessandro, F.; Barbaro, G.; Malara, G. General longshore transport model. Coast. Eng. 2013, 71, 28-36. [CrossRef]

82. Lamberti, A.; Tomasicchio, G.R. Stone mobility and longshore transport at reshaping breakwaters. Coast. Eng. 1997, 29, 263-289. [CrossRef]

83. Gavrilovic, S. Méthode de la Classification des Bassins Torrentiels et Équations Nouvelles Pour le Calcul des Hautes Eaux et du Débit Solide; Vadoprivreda: Belgrado, Serbia, 1959. (In French)

84. Giandotti, M. Previsione Delle Piene e delle Magre dei corsi d'acqua; Servizio Idrografico Italiano, Memorie e Studi Idrografici: Roma, Italy, 1934; Volume 8, pp. 8-13. (In Italian) 
85. Kirpich, Z.P. Time of concentration of small agricultural watersheds. Civ. Eng. 1940, 10, 362.

86. Natural Resources Conservation Service (NRCS). Pondsplanning, Design Construction. Agriculture Handbook; United States Department of Agriculture (USDA): Washington, DC, USA, 1997.

87. ASCE. Hydrology Handbook; ASCE Manuals and Reports on Engineering Practice n. 28; ASCE: Reston, VA, USA, 1996. [CrossRef]

88. Fiedler, F.R. Simple, Practical Method for Determining Station Weights Using Thiessen Polygons and Isohyetal Maps. J. Hydrol. Eng. 2003, 8, 219-221. [CrossRef]

89. Boak, E.H.; Turner, I. Shoreline Definition and Detection: A Review. J. Coast. Res. 2005, 214, 688-703. [CrossRef]

90. Hapke, C.J.; Himmelstoss, E.A.; Kratzmann, M.G.; List, J.H.; Thieler, E.R. National Assessment of Shoreline Change: Historical Shoreline Change along the New England and Mid-Atlantic Coasts; Open-File Report 1118; US Geological Survey: Reston, Virginia, 2010. [CrossRef] 